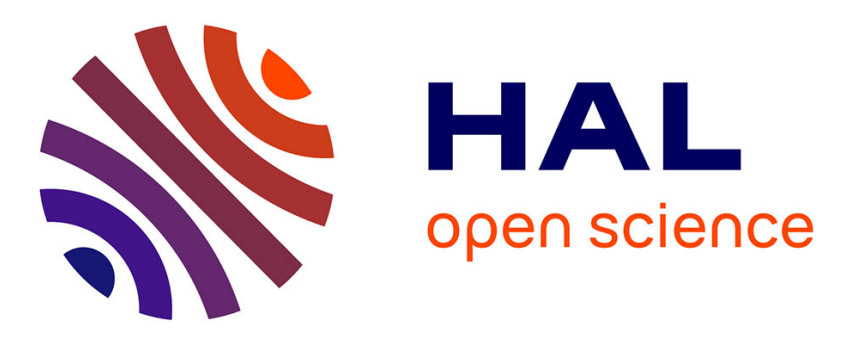

\title{
Stratospheric Radiometric Measurements from Constant-Level Balloons
}

\author{
Alain Hauchecorne, Jean-Pierre Pommereau
}

\section{To cite this version:}

Alain Hauchecorne, Jean-Pierre Pommereau. Stratospheric Radiometric Measurements from Constant-Level Balloons. Journal of Applied Meteorology, 1979, 18 (11), pp.1385-1396. 10.1175/1520-0450(1979)0182.0.CO;2 . insu-03117381

\section{HAL Id: insu-03117381 https://hal-insu.archives-ouvertes.fr/insu-03117381}

Submitted on 21 Jan 2021

HAL is a multi-disciplinary open access archive for the deposit and dissemination of scientific research documents, whether they are published or not. The documents may come from teaching and research institutions in France or abroad, or from public or private research centers.
L'archive ouverte pluridisciplinaire HAL, est destinée au dépôt et à la diffusion de documents scientifiques de niveau recherche, publiés ou non, émanant des établissements d'enseignement et de recherche français ou étrangers, des laboratoires publics ou privés. 


\title{
Stratospheric Radiometric Measurements from Constant-Level Balloons
}

\author{
A. Hauchecorne and J. P. Pommereau \\ Service d'Aéronomie du Centre National de la Recherche Scientifique, Verrières-le-Buisson, France
}

(Manuscript received 20 March 1979, in final form 25 July 1979)

\begin{abstract}
Superpressure balloons are used as radiometers to perform in-situ radiometric determinations in the lower stratosphere. The method consists in measuring the temperature of both the lifting gas and the ambient air and then computing the incident fluxes through the thermal balance equation. Data obtained from six flights at the $100 \mathrm{mb}$ level from 1974 to 1978 in the tropics and the Southern Hemisphere are presented. As far as the tropospheric thermal radiation is concerned, the data are in general agreement with previous balloon and satellite measurements, although they show a greater variation with the underlying surface under clear-sky conditions. Over the most extreme conditions (high-level clouds) they demonstrate that the radiation temperature is always higher, by at least $9 \mathrm{~K}$ (minimum difference at the equator), than the temperature at $100 \mathrm{mb}$. The albedo inferred from the solar flux absorbed by a spherical balloon, taking into account the increase of the directional reflectance with zenith angle, is in good agreement with satellite measurements.
\end{abstract}

\section{Introduction}

At float altitude a superpressure balloon is in thermal balance with the surrounding atmosphere. Heat losses of the balloon by thermal radiation and free convection are balanced by the absorbed sunlight and ground and atmospheric thermal radiations. Measurement of the ambient air and helium temperatures allows determination of each term of the thermal balance equation at night and thus gives the upwelling thermal radiation: the balloon itself is used as a radiometer. During the day the cloud cover identified by satellite pictures compared with measurements performed at night under the same conditions gives the earth thermal radiation term and thus allows a study of the solar albedo.

We present results of thermal radiation and albedo measurements made on-board superpressure balloons at the $100 \mathrm{mb}$ level $(16000 \mathrm{~m})$ over both equatorial regions and throughout the Southern Hemisphere from 1974 to 1978.

\section{Theory of the balloon as a radiometer \\ a. Balloon thermal balance in-flight}

The thermal balance of the balloon at ceiling altitude may be expressed as

$$
\alpha_{s}{ }^{\mathrm{eff}} E_{s}+\alpha_{t}^{\mathrm{eff}} E_{t}=E_{b}+E_{c},
$$

where $E_{s}$ and $E_{t}$ are the energies of solar and thermal radiation intercepted by the balloon, $\alpha_{s}{ }^{\text {eff }}$ and $\alpha_{t}{ }^{\text {eff }}$ the balloon effective absorptances for the solar and thermal spectral bands, respectively, while $E_{b}$ and $E_{c}$ are the heat losses by thermal radiation and free convection. The experimental time constant of the balloon thermal equilibrium, as determined for example through day-night variation, is $\sim 5 \mathrm{~min}$. The perturbation by the equipment array hanging below the balloon may be neglected in Eq. (1) because it blocks less than $1 \%$ of the incident flux.

\section{1) ABSORBED SOLAR RADIATION}

The sunlight received by the balloon is composed of direct solar radiation $E_{d}$ and radiation reflected from clouds and the ground and scattered by the atmosphere $E_{r}$, i.e.,

$$
E_{s}=E_{d}+E_{r} .
$$

The solar constant may be expressed as

$$
C=\int_{\lambda=0}^{\infty} \phi_{s}(\lambda) d \lambda
$$

where $\phi_{s}(\lambda)$ is the solar spectral flux at the wavelength $\lambda$ at the mean sun-to-earth distance.

The solar radiation is partially absorbed in the stratosphere above the balloon level. It intercepts a direct solar energy

$$
E_{d}=\pi r^{2} C e^{-\pi(x, z)} / D^{2}
$$

where $z$ is the balloon altitude, $\chi$ the solar zenith angle and $D$ the earth-sun distance in astronomical units. The mean optical thickness for the solar radiation $\tau(\chi, z)$ is defined as

(C) 1979 American Meterological Society. 


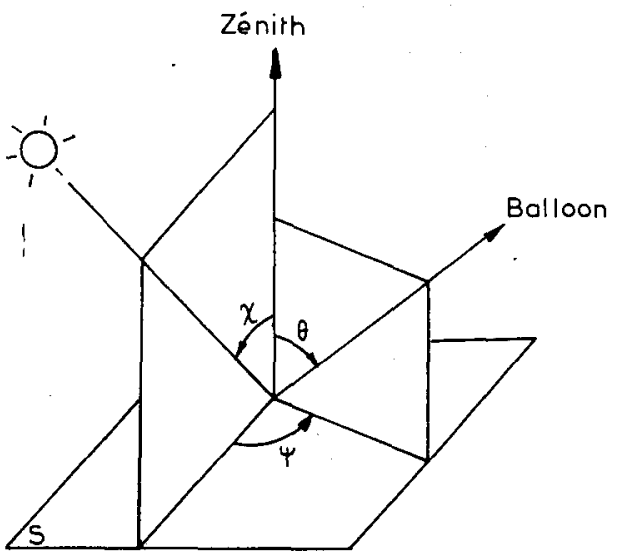

FIG. 1. Observation geometry of the reflected and scattered solar flux.

$$
\int_{0}^{\infty} e^{-\tau(\chi, z) \sec (\chi)} \phi_{s}(\lambda) d \lambda / C=e^{-\pi(\chi, z)} .
$$

Its value, computed through the vertical profile of the stratospheric absorbing gases, is $\sim 0.03$ for $\sec (\chi)=1$. The balloon also intercepts upward solar radiation reflected from ground or clouds and scattered by the atmosphere. The specific intensity of such radiation can be written as

$$
I_{s}(\lambda, \theta, \psi)=\phi_{s}(\lambda) \cos \chi R(\lambda, \theta, \psi) / \pi D^{2},
$$

where $R(\lambda, \theta, \psi)$ is the bi-directional spectral reflectance of the surface-atmosphere system. The angles $\theta$ and $\psi$ are defined in Fig. 1. Since any beam $(\theta, \psi)$ "sees" a balloon of cross section $\pi r^{2}$, the energy intercepted by the balloon is given by integrating over the upwelling solid angle $2 \pi$ to yield

$$
\begin{aligned}
E_{r}(\lambda) & =\pi r^{2} \int_{0}^{\pi / 2} \int_{0}^{2 \pi} I_{s}(\lambda, \theta, \psi) \sin \theta d \psi d \theta, \\
E_{r} & =\int_{0}^{\infty} E_{r}(\lambda) d \lambda .
\end{aligned}
$$

The balloon effective spectral absorptivity $\alpha_{\text {eff }}(\lambda)$ (Fig. 2) is computed using the thermo-optical coefficients of the material $[\alpha(\lambda)$ absorptivity, $t(\lambda)$ transmissivity and $r(\lambda)$ reflectivity] by taking into account multiple reflections inside the balloon:

$$
\alpha_{\mathrm{err}}(\lambda)=\left[1+\frac{t(\lambda)}{1-r(\lambda)}\right] \alpha(\lambda),
$$

and the effective absorptivity for direct sunlight $\left(\alpha_{s}{ }^{d}\right)$ is computed from $\alpha_{\text {eff }}(\lambda)$ and the direct solar spectrum (Fig. 2):

$$
\alpha_{s}{ }^{d}=\int_{0}^{\infty} \phi_{s}(\lambda) \alpha_{\mathrm{eff}}(\lambda) d \lambda / C .
$$

The reflected solar spectrum differs slightly from the direct solar spectrum. Although the effective ab- sorptivity of a mylar balloon is about constant between 0.38 and $2.2 \mu \mathrm{m}$, the wavelength interval in which $90 \%$ of the solar flux is included, it rises at wavelengths above $2.2 \mu \mathrm{m}$ so that $18 \%$ of the absorbed solar flux lies in this spectral interval. The balloon effective absorptivity for the reflected solar radiation $\alpha_{s}{ }^{r}$ differs by 5-10\% from the value $\alpha_{s}{ }^{d}$ for the direct radiation because of the infrared absorption bands of atmospheric water vapor.

\section{2) EARTH AND ATMOSPHERIC THERmal RADIA- TION}

The ground, the clouds and the atmosphere all radiate in the infrared, the emissivity of the ground and the clouds varying between 0.9 and 1.0. The emitted radiation is partially absorbed and reemitted by atmospheric water, carbon dioxide and ozone. If we assume that both the emitting surface and the atmosphere between it and the balloon are horizontally homogeneous, the energy intercepted by the balloon from the upward thermal radiation is

$$
E_{t}(\lambda) \uparrow=\pi r^{2} \int_{0}^{\pi / 2} \int_{0}^{2 \pi} I_{t}(\lambda, \theta) \sin \theta d \psi d \theta,
$$

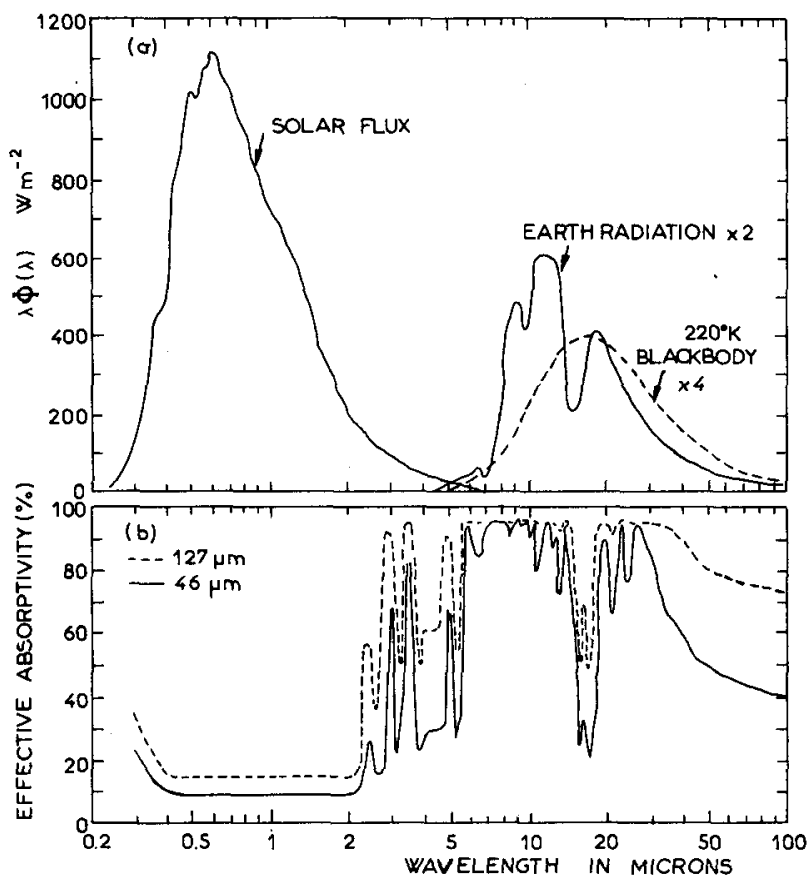

FIG. 2a. Spectral distribution of extraterrestrial solar flux, up ward thermal flux at the top of the atmosphere for clear conditions [Nimbus 3 measurements, $13^{\circ} \mathrm{N}$, June 1969 (R. G. Ellingson and J. G. Gille, 1978)] and blackbody radiation at $220 \mathrm{~K}$. This graph shows the product of the wavelength $\lambda$ by the spectral flux $\phi(\lambda)$ such that the area is proportional to the flux. The earth thermal radiation is multiplied by 2 and the blackbody radiation by 4 to take into account the surface coefficient in the thermal balance equation of the balloon.

Fig. 2b. Spectral effective absorptivity for 127 and $46 \mu \mathrm{m}$ thickness mylar films, computed through the thermooptical coefficients of the fabrics measured in laboratory. 


$$
E_{t} \uparrow=\int_{0}^{\infty} E_{t}(\lambda) \uparrow d \lambda,
$$

where $I_{t}(\lambda, \theta)$ is the specific intensity of the thermal radiation.

The balloon also intercepts energy from the downward thermal radiation, i.e.,

$$
\begin{aligned}
E_{t}(\lambda) \downarrow & =\pi r^{2} \int_{\pi / 2}^{\pi} \int_{0}^{2 \pi} I_{t}(\lambda, \theta) \sin \theta d \psi d \theta, \\
E_{t} \downarrow & =\int_{0}^{\infty} E_{t}(\lambda) \downarrow d \lambda,
\end{aligned}
$$

The calculation of $I_{t}(\lambda, \theta)$ at the balloon level involves integrating the equation of transfer through the atmosphere, starting from the emitting surface (ground, sea or clouds) of presumably known temperature and emissivity.

The balloon effective absorptivity for the earth and atmospheric radiation is computed, as for sunlight, using the spectral effective absorptivity $\alpha_{\text {eff }}(\lambda)$ and the atmospheric infrared spectra taking into account water vapor, carbon dioxide and ozone (Fig. 2), i.e.,

$$
\alpha_{t}^{\mathrm{eff}}=\int_{0}^{\infty} \alpha_{\mathrm{eff}}(\lambda) E_{t}(\lambda) \uparrow d \lambda / E_{t} \uparrow .
$$

Values of $\alpha_{t}^{\text {eff }}$ have been computed for a radiation temperature for ground and clouds varying between 200 and $300 \mathrm{~K}$ and for a dry and a saturated atmosphere. The variation of $\alpha_{t}^{\text {eff }}$ is less than $5 \%$.

\section{3) BALloon-HEAT LOSS BY THERMAL RADIATION}

The balloon itself radiates in the infrared with a spectral emissivity

$$
\epsilon_{\text {eff }}(\lambda)=\alpha_{\text {eff }}(\lambda) .
$$

The balloon gas emissivity (helium) is negligible. The total rate of heat loss is

$$
E_{b}=4 \pi r^{2} \int_{0}^{\infty} \phi_{b}(\lambda) d \lambda
$$

with

$$
\phi_{b}(\lambda)=\alpha_{\mathrm{eff}}(\lambda) B_{\lambda}\left(T_{b}\right) .
$$

Here $T_{b}$ is the mean temperature of the balloon envelope and $B_{\lambda}\left(T_{b}\right)$ is the Planck function.

The effective emissivity $\epsilon_{t}^{\text {eff }}$ is computed, as was done for solar and infrared absorptivity, using the spectral effective absorptivity $\alpha_{\text {eff }}(\lambda)$, and the blackbody infrared spectrum at the temperature $T_{b}$ (Fig. 2):

$$
\epsilon_{t}{ }^{\mathrm{eff}}=\int_{0}^{\infty} \alpha_{\mathrm{eff}}(\lambda) B_{\lambda}\left(T_{b}\right) d \lambda \sigma \sigma T_{b}{ }^{4},
$$

where $\sigma$ is Stefan's constant. For a mylar stratospheric balloon the ratio $\epsilon_{t}{ }^{\text {eff }} / \alpha_{t}^{\text {eff }}$ varies between
0.95 and 0.99 depending on radiative conditions and material thickness.

In fact, the balloon envelope temperature is not homogeneous because the upward thermal radiation warms the balloon bottom. The equilibrium temperature of its upper and its lower parts, $T_{u}$ and $T_{l}$, may be computed separately through two equations like Eq. (1) which include the thermal transfer radiation between the two parts. The computed difference between $T_{u}$ and $T_{l}$ is some $15^{\circ} \mathrm{C}$. The energy emitted by the balloon is then

$$
E_{b}{ }^{1}=2 \pi r^{2} \epsilon_{t}{ }^{\text {eff }}\left(\sigma T_{u}{ }^{4}+\sigma T_{l}{ }^{4}\right) .
$$

The energy emitted by a balloon at a mean temperature

$$
T_{b}=\left(T_{u}+T_{l}\right) / 2,
$$

would be

$$
E_{b}=4 \pi r^{2} \epsilon_{t}^{\mathrm{eff}} \sigma\left(\frac{T_{u}+T_{l}}{2}\right)^{4},
$$

which differs by less than $1 \%$ from $E_{b}{ }^{1}$ for a $15^{\circ} \mathrm{C}$ difference between $T_{u}$ and $T_{l}$. Convection created by the negative vertical gradient of temperature inside the balloon homogenizes the balloon gas temperature $T_{g}$. This was shown by measurements on several flights at the upper and the lower part of the balloon. The gas temperature difference between these two locations is less than $1{ }^{\circ} \mathrm{C}$. The heat transfer from the lower part of the balloon to the gas balances the heat transfer from the gas to the upper part when

$$
\begin{gathered}
T_{l}-T_{g}=T_{g}-T_{u}, \\
T_{g}=\left(T_{u}+T_{l}\right) / 2=T_{b} .
\end{gathered}
$$

The measured gas temperature is then equal to the balloon mean temperature $T_{b}$ with an accuracy of $2^{\circ} \mathrm{C}$.

\section{4) Balloon heat loss by free Convection}

At ceiling altitude a superpressure balloon is motionless relative to the atmosphere. If it is warmer or cooler than the surrounding air, it can lose or gain heat by free convection. The thermal measurements that we carried out on stratospheric balloons showed that the free convection is laminar. The rate of heat loss is computed using the value of the Nusselt number $\mathrm{Nu}$ associated with free convection in laminar flow (Handbook of Heat Transfer, 1973):

$$
\begin{aligned}
E_{c}=4 \pi r^{2} \operatorname{Nu}\left(T_{b}\right. & \left.-T_{a}\right) k / 2 r \\
& =3.6 \pi r^{2}\left(T_{b}-T_{a}\right)^{5 / 4} r^{-1 / 4} \rho^{1 / 2}
\end{aligned}
$$

where $T_{a}, \rho$ and $k$ are the air temperature, density and thermal conductivity, respectively.

\section{b. Earth thermal radiation measurements at night}

At night the helium temperature gives the earth upward radiation intercepted by the balloon, i.e., 


$$
E_{t} \uparrow=4 \pi r^{2} \sigma T_{b}{ }^{4} \epsilon_{t}{ }^{\text {eff }} / \alpha_{t}{ }^{\text {eff }}+E_{c} / \alpha_{t}{ }^{\text {eff }}-E_{t} \downarrow .
$$

The convective term represents only $5-10 \%$ of $E_{t} \uparrow$.

The upward thermal flux measured by a $1 \mathrm{~m}^{2}$ horizontal radiometer at the balloon level is

$$
\phi_{t}(\lambda) \uparrow=\int_{0}^{\pi / 2} \int_{0}^{2 \pi} I_{t}(\lambda, \theta) \sin \theta \cos \theta d \psi d \theta
$$

which may be expressed as

$$
\begin{aligned}
& \text { with } \quad \phi_{t}(\lambda) \uparrow=K_{t}(\lambda) \uparrow E_{t}(\lambda) \uparrow / 2 \pi r^{2} \\
& \qquad K_{t}(\lambda) \uparrow=\frac{2 \int_{0}^{\pi / 2} \int_{0}^{2 \pi} I_{t}(\lambda, \theta) \sin \theta \cos \theta d \psi d \theta}{\int_{0}^{\pi / 2} \int_{0}^{2 \pi} I_{t}(\lambda, \theta) \sin \theta d \psi d \theta} .
\end{aligned}
$$

The total upward flux is then

with

$$
\phi_{t} \uparrow=K_{t} \uparrow E_{t} \uparrow / 2 \pi r^{2}
$$

$$
K_{t} \uparrow=\int_{0}^{\infty} K_{t}(\lambda) \uparrow E_{t}(\lambda) \uparrow d \lambda / E_{t} \uparrow .
$$

$K_{t} \uparrow$ is computed taking into account the decrease of the atmospheric transmission when $\theta$ increases (Mantis, 1961) and the earth's curvature which reduces the solid angle corresponding to the earth seen by the balloon. Assuming a mean altitude of 6 $\mathrm{km}$ for the emissive surface and $17 \mathrm{~km}$ for the balloon, the value of $K_{t} \uparrow$ is 1.12 . Similarly, the downward thermal flux $\phi_{t} \downarrow$ is

$$
\phi_{t} \downarrow=K_{t} \downarrow E_{t} \downarrow / 2 \pi r^{2} \approx E_{t} \downarrow / 2 \pi r^{2} .
$$

The thermal flux $\phi_{t} \downarrow$ is some $10 \mathrm{~W} \mathrm{~m}^{-2}$ at the $100 \mathrm{mb}$ level according to Ellingson and Gille (1978). The estimated standard error of the earth's radiation measurements may be deduced from individual errors of the terms entering into Eq. (31) and Eq. (32):

$$
\begin{aligned}
& \Delta T_{b}= \pm 2^{\circ} \mathrm{C}, \quad \Delta \phi_{t} \downarrow= \pm 5 \mathrm{~W} \mathrm{~m}^{-2}, \\
& \frac{\Delta E_{c}}{E_{c}}= \pm 0.30, \quad \Delta\left(\frac{\epsilon_{t}^{\text {eff }}}{\alpha_{t}^{\text {eff }}}\right)= \pm 0.03, \\
& \frac{\Delta \alpha_{t}^{\text {eff }}}{\alpha_{t}^{\text {eff }}}= \pm 0.10, \quad \Delta K_{t} \uparrow= \pm 0.04 .
\end{aligned}
$$

For a typical $\phi_{t} \uparrow$ of $250 \mathrm{~W} \mathrm{~m}^{-2}$, the standard error is $\pm 20 \mathrm{~W} \mathrm{~m}^{-2}$. When two measurements are compared only the precision of the result is to be considered. The smallest change of $\phi_{t} \uparrow$ that can be resolved by the experiment is $\Delta \phi_{t} \uparrow= \pm 6 \mathrm{~W} \mathrm{~m}^{-2}$ when $\phi_{t} \uparrow$ $=250 \mathrm{~W} \mathrm{~m}^{-2}$, due to the $\pm 1^{\circ} \mathrm{C}$ resolution of the $T_{b}$ measurements.

\section{c. Solar albedo determination}

During the day, the balloon thermal balance may be written $\alpha_{t}^{\text {eff }}\left(E_{t} \uparrow+E_{t} \downarrow\right)+\alpha_{s}^{d} E_{d}+\alpha_{s}^{r} E_{r}=E_{b}+E_{c}$.

The solar spectral albedo is

$$
\begin{aligned}
A(\lambda)= & \frac{D^{2}}{\cos \chi \phi_{s}(\lambda)} \\
& \times \int_{0}^{\pi / 2} \int_{0}^{2 \pi} I_{s}(\lambda, \theta, \psi) \sin \theta \cos \theta d \psi d \theta,
\end{aligned}
$$

which is related to the reflected solar radiation intercepted by the balloon

where

$$
A(\lambda)=K_{s}(\lambda) E_{r}(\lambda) D^{2} /\left(2 \pi r^{2} \phi_{s}(\lambda) \cos \chi\right),
$$

$K_{s}(\lambda)=\frac{2 \int_{0}^{\pi / 2} \int_{0}^{2 \pi} I_{s}(\lambda, \theta, \psi) \sin \theta \cos \theta d \psi d \theta}{\int_{0}^{\pi / 2} \int_{0}^{2 \pi} I_{s}(\lambda, \theta, \psi) \sin \theta d \psi d \theta}$.

The solar albedo is then

with

$$
A=K_{s} E_{r} D^{2} /\left(2 \pi r^{2} C \cos \chi\right)
$$

$$
K_{s}=\int_{0}^{\infty} K_{s}(\lambda) \phi_{s}(\lambda) d \lambda / C .
$$

The factor $K_{s}$ is estimated from the increase of the directional reflectance with zenith angle given by Raschke (1969): $K_{s}=0.87$. The solar albedo may be computed using Eq. (33) if the upwelling thermal radiation is known. This is the case when infrared satellite pictures show the same cloud cover during the previous or the following night and when the thermal flux $\phi_{t} \uparrow$ deduced from our measurements is constant during the night. The atmospheric temperature changes by less than $1^{\circ} \mathrm{C}$ between day and night at the $100 \mathrm{mb}$ level according to our measurements in flight. The albedo is expressed as

$$
\begin{aligned}
& A=\frac{K_{s} D^{2}\left(L_{d}-L_{n}-\alpha_{s}{ }^{d} E_{d}\right)}{2 \pi r^{2} \alpha_{s}{ }^{r} C \cos \chi}, \\
& A=\frac{K_{s} D^{2}\left(L_{d}-L_{n}\right)}{2 \pi r^{2} \alpha_{s}{ }^{r} C \cos \chi}-\frac{K_{s} D^{2} e^{-\tau(\chi, z)} \alpha_{s}{ }^{d}}{2 \cos \chi \alpha_{s}{ }^{r}},
\end{aligned}
$$

where

$$
L=E_{b}+E_{c}-\alpha_{t}^{\text {eff }}\left(E_{t} \uparrow-E_{t} \downarrow\right),
$$

with subscripts $d$ and $n$ for day and night measurements, respectively.

The estimated standard error of the albedo is deduced in the same way as for the infrared radiation. Systematic errors in $L$ tend to cancel when calculating $A$ but we must consider the accuracy with which variations between day and night of each term of $L$ is determined. We estimate that the accuracy of the $T_{b}$ variations, which enter into $E_{b}$ and $E_{c}$, is $\pm 1^{\circ} \mathrm{C}$ and that $\phi_{t} \uparrow$ may vary by $\pm 6 \mathrm{~W} \mathrm{~m}^{-2}$ for the day/ night couples we have used. The errors on the varia- 
tion between night and day of the different terms of Eq. (40) are then

$$
\begin{aligned}
\Delta\left(E_{b}{ }^{d}-E_{b}{ }^{n}\right) / 2 \pi r^{2} & = \pm 7 \mathrm{~W} \mathrm{~m}^{-2}, \\
\Delta\left(E_{c}{ }^{d}-E_{c}{ }^{n}\right) / 2 \pi r^{2} & = \pm 9 \mathrm{~W} \mathrm{~m}^{-2}, \\
\Delta\left(L_{d}-L_{n}\right) / 2 \pi r^{2} & = \pm 15 \mathrm{~W} \mathrm{~m}^{-2} .
\end{aligned}
$$

Our estimates of the errors are

$$
\begin{gathered}
\Delta \alpha_{s}^{r} / \alpha_{s}^{r}= \pm 0.10, \quad \Delta K_{s} / K_{s}= \pm 0.10, \\
\Delta e^{-\tau(X, z)} / e^{-\tau(X, z)}= \pm 0.02 .
\end{gathered}
$$

Moreover, there may be a difference of $10 \%$ between the effective absorptivity for direct and reflected solar radiation: $\Delta\left(\alpha_{s}{ }^{d} / \alpha_{s}{ }^{r}\right)= \pm 0.10$. The standard error of $A$ increases from $\Delta A= \pm 0.12$ to $\Delta A= \pm 0.17$ when $A$ increases from 0 to 0.80 . The smallest change of $A$ that can be resolved is $\Delta A$ $= \pm 0.05$ due to the resolution of $T_{b}\left( \pm 1^{\circ} \mathrm{C}\right)$ and the steadiness of $\phi_{i} \uparrow\left( \pm 6 \mathrm{~W} \mathrm{~m}^{-2}\right)$.

\section{Description of the experiment}

The experimental data discussed come from three series of flights of superpressure mylar balloons at $100 \mathrm{mb}(16 \mathrm{~km})$ : the first one took place in September 1974 with three $10 \mathrm{~m}$ diameter balloons, the second in October 1975 with three $5.60 \mathrm{~m}$ balloons. They were launched from the French Space Center at Kourou (French Guiana). The third series with three $5.60 \mathrm{~m}$ balloons was launched in April 1978, from the French Station at Pretoria (South Africa).

The $10 \mathrm{~m}$ balloons were made of bilaminated mylar of $127 \mu \mathrm{m}$ thickness and the $5.60 \mathrm{~m}$ of bilaminated mylar of $46 \mu \mathrm{m}$ thickness. The balloon thermooptical coefficients, for clear sky thermal radiation and a balloon mean temperature of $220 \mathrm{~K}$ computed from the material coefficients, are shown in Table 1. Fig. 3 shows the payload equipment. The balloon supported the equipment which provided the following on board measurements:

- Differential pressure between the helium lifting gas and the ambient air made by a sensor mounted at the upper pole of the balloon.

- Helium gas temperature inside the balloon measured by a microhead thermistor $(\phi=0.1 \mathrm{~mm})$ mounted as shown in Fig. 4. This mounting, tested on numerous free balloon flights, is reliably capable of measuring gas temperature to $\pm 1^{\circ} \mathrm{C}$.

- Ambient air temperature, also measured by a microhead thermistor with an absolute accuracy of $\pm 2^{\circ} \mathrm{C}$.

- Solar elevation, used to determine the balloon's position, made by a vertically mounted sensor developed by the National Center for Atmospheric Research (Lally et al., 1967).

The signal conditioner and telemetry transmitter
TABLE 1. Balloon thermooptical coefficients.

\begin{tabular}{cccc}
\hline $\begin{array}{c}\text { Material } \\
\text { thickness } \\
(\mu \mathrm{m})\end{array}$ & $\alpha_{s}{ }^{d}$ & $\alpha_{t}{ }^{\text {eff }}$ & $\epsilon_{t}{ }^{\text {eff }}$ \\
\hline 127 & 0.15 & 0.88 & 0.87 \\
46 & 0.09 & 0.74 & 0.72 \\
\hline
\end{tabular}

are powered by solar cells during the day, and by an array of lithium batteries at night. Both the battery package and the telemetry electronics are covered by aluminized cones designed to capture upwelling thermal radiation at night, and to protect the units from the excessively low stratospheric temperatures down to $-80^{\circ} \mathrm{C}$. The telemetered information from these four sensors is transmitted by a Morse code HF transmitter to a network of receiving stations.

Aside from the four measurements made on board, additional sources of information were used for the understanding of the flight environment:

- Regular rawinsondes launched from Cayenne and Pretoria.

- Special radio sondes launched from the range one hour after each balloon launch to measure temperature, pressure and wind.

- Reports prepared by the staff meteorologist of local cloud patterns through visual and radar observations.

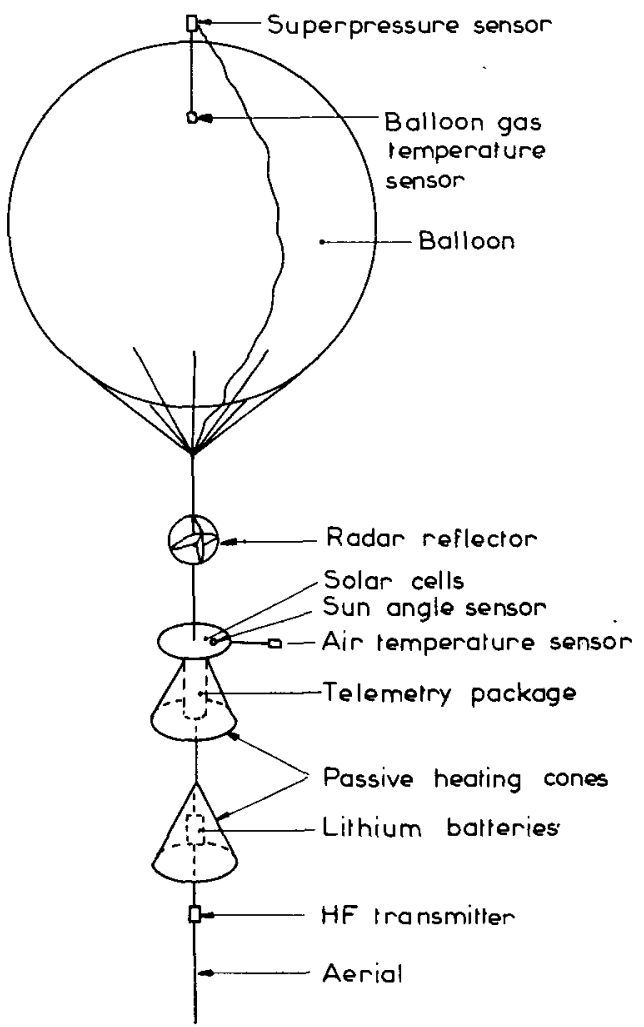

FIG. 3. Flight configuration. 


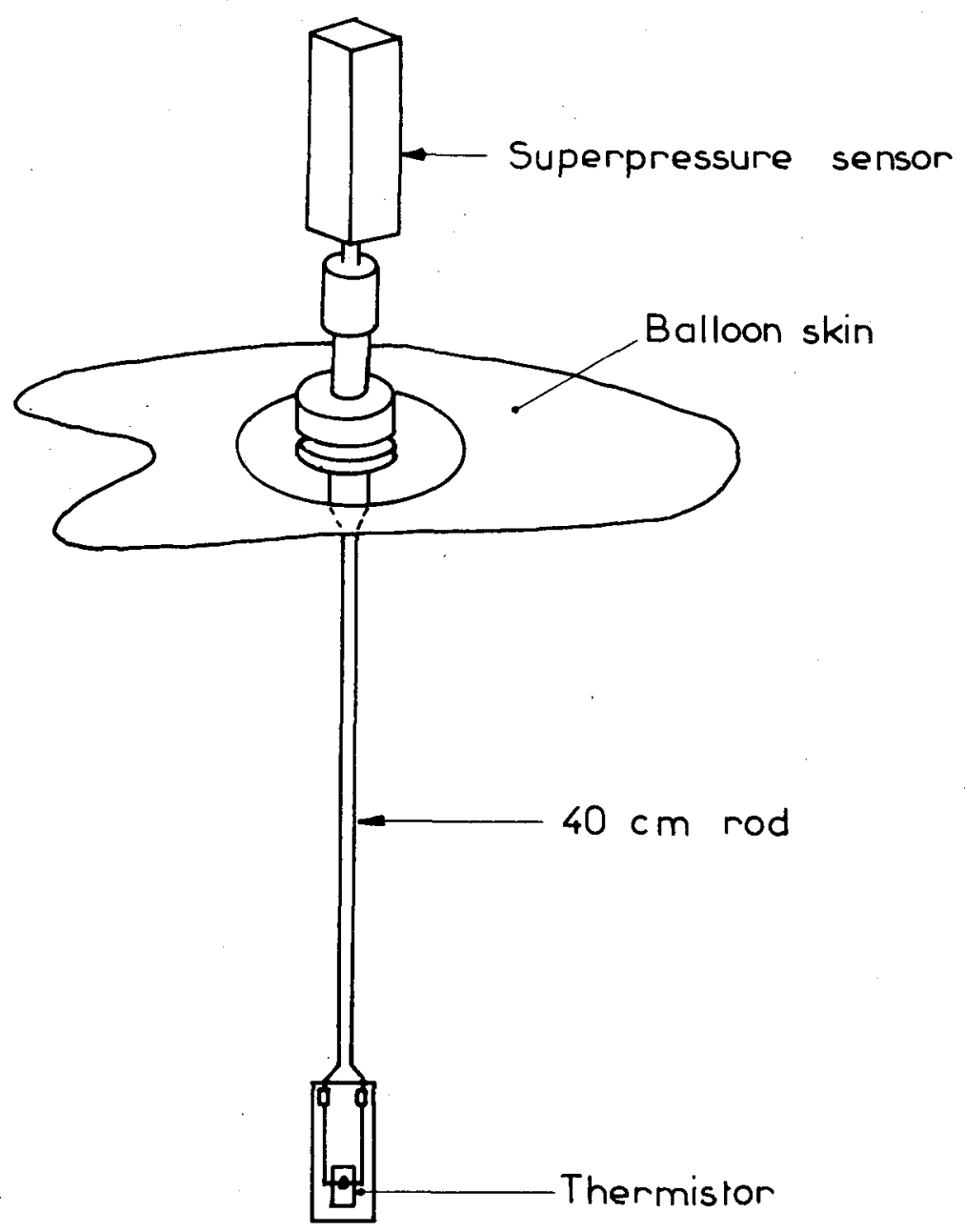

FIG. 4. Detail of superpressure and gas temperature sensor mounting.

- Reception of visible and infrared satellite photographies of the region (ESSA 8 and NOAA 2, in 1975; METEOSAT in 1978).

- Reception of facsimiles of weather charts of the region.

For the 1975 flights, the cloud cover along the balloon trajectories was analyzed using the infrared pictures at wavelengths of 6.7 and $11.5 \mu \mathrm{m}$ taken by the satellite Nimbus 6.

During the 1974 campaign three $10 \mathrm{~m}$ balloons were flown. Two of these balloons had significant leaks and provided data during the first day of flight only. The third balloon flew well for four days, then failed by adverse thermal conditions which caused excessive cooling of the lifting gas and a resulting loss of balloon lift. The trajectory of this flight is indicated in Fig. 5.

In 1975, the first balloon flew only for a few hours but the subsequent two balloons remained aloft for two and three months, respectively. The trajectories are shown in Fig. 5. Night data are available only for the first month because of the limited energy of the lithium battery arrays.

In 1978, the first and the second flights provided two and three weeks, respectively of day and night data. The third balloon fell after four days of flight because of a fabrics defect. The trajectories are shown on Fig. 5. Although the data cover areas from equatorial to polar regions, the main part of night results concerns the equatorial and tropical regions.

\section{Results \\ a. Analysis of experimental data}

From the ambient air and gas temperature measurements one can decompose the thermal balance equation into its four terms: balloon radiation, free convection, and earth and solar radiation. The solar radiation is divided into direct and reflected components allowing the computation of the albedo. Fig. 6 shows the results of the first $36 \mathrm{~h}$ of flight of the 


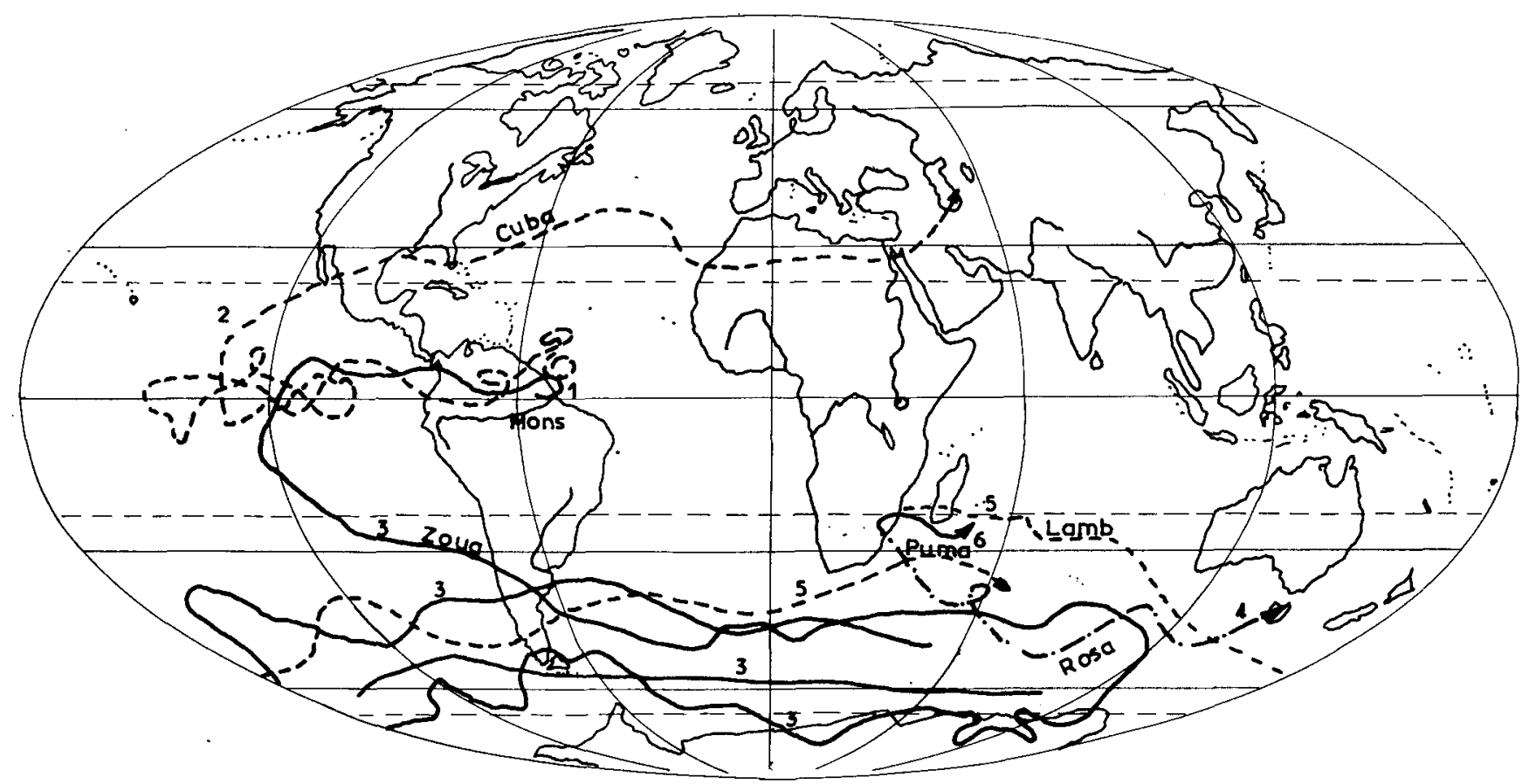

FIG. 5. Trajectories of balloons. Three balloons were launched from the French Space Center at Kourou: (1) balloon MONS, September 1974, (2) balloon CUBA, October-December 1975, (3) balloon ZOUG, October 1975-January 1976. The three others were launched from the French Satellite Station at Pretoria: (4) balloon ROSA, April 1978, (5) balloon LAMB, April 1978, (6) balloon PUMA, April 1978.

balloon MONS in 1974. The cloud pattern to be compared with these measurements was determined by visual and radar observations. The same analysis was made on the temperature measurements from the two long-duration flights in 1975 . Fig. 7 shows the variation over $24 \mathrm{~h}$ of the temperature difference between ambient air and the balloon gas for various cases of cloud cover and latitudes. The upwelling thermal flux and the albedo are inferred from these experimental results, the same way as indicated above.

\section{b. Earth and atmospheric radiation in the strato- sphere}

The determinations of the upwelling flux through a horizontal surface at the $100 \mathrm{mb}$ level are listed in Table 2 for clear-sky conditions and in Table 3 for high-altitude clouds corresponding to minimum values. These data are compared in Tables 2 and 3 and in Fig. 8 with those obtained by various authors:

- Measurements at $100 \mathrm{mb}$ made by night on board radiosonde balloons with three different radiometers during the International Radiometersonde Intercomparison Program (Gille and Kuhn, 1973).

- Satellite experimental results by Vonder Haar (1970) from Nimbus 3, Mc Leese and Wilson (1976) from the Nimbus 5 SCR experiment at $15 \mu \mathrm{m}$, and Smith et al. (1974) from the Nimbus
5 ITPR experiment over the entire infrared spectrum.

They are also compared with theoretical model results of the upwelling thermal flux at the $100 \mathrm{mb}$ level from Ellingson and Gille (1978) and Cox and Griffith (1979).

\section{1) High-Level clouds}

The upward thermal flux is much lower over high clouds than in clear conditions, especially in equatorial regions $\left(95 \mathrm{~W} \mathrm{~m}^{-2}\right.$ vs $245 \mathrm{~W} \mathrm{~m}^{-2}$ ). Fig. 9 compares the radiation temperature of high clouds (the equivalent blackbody temperature) with the ambient temperature at the balloon level $(100 \mathrm{mb})$ which is not far from the tropopause temperature in tropical regions. These results may be compared with those of Mc Leese and Wilson (1976) near the equator and with the model of Cox and Griffith (1979) (Fig. 9). The radiation temperature is always higher than the ambient temperature at $100 \mathrm{mb}$. The smallest difference between these two temperatures is $9^{\circ} \mathrm{C}$ at the equator and $15^{\circ} \mathrm{C}$ at $45^{\circ} \mathrm{S}$. Cox and Griffith (1979) show with theoretical computations of the thermal radiation based on measurements of cloud water content, that when the top of a cloud is at 100 $\mathrm{mb}$, the upward radiation is emitted at a mean altitude of $1660 \mathrm{~m}$ below the cloud top. If the temperature profile is that of the U.S. Standard Atmosphere 


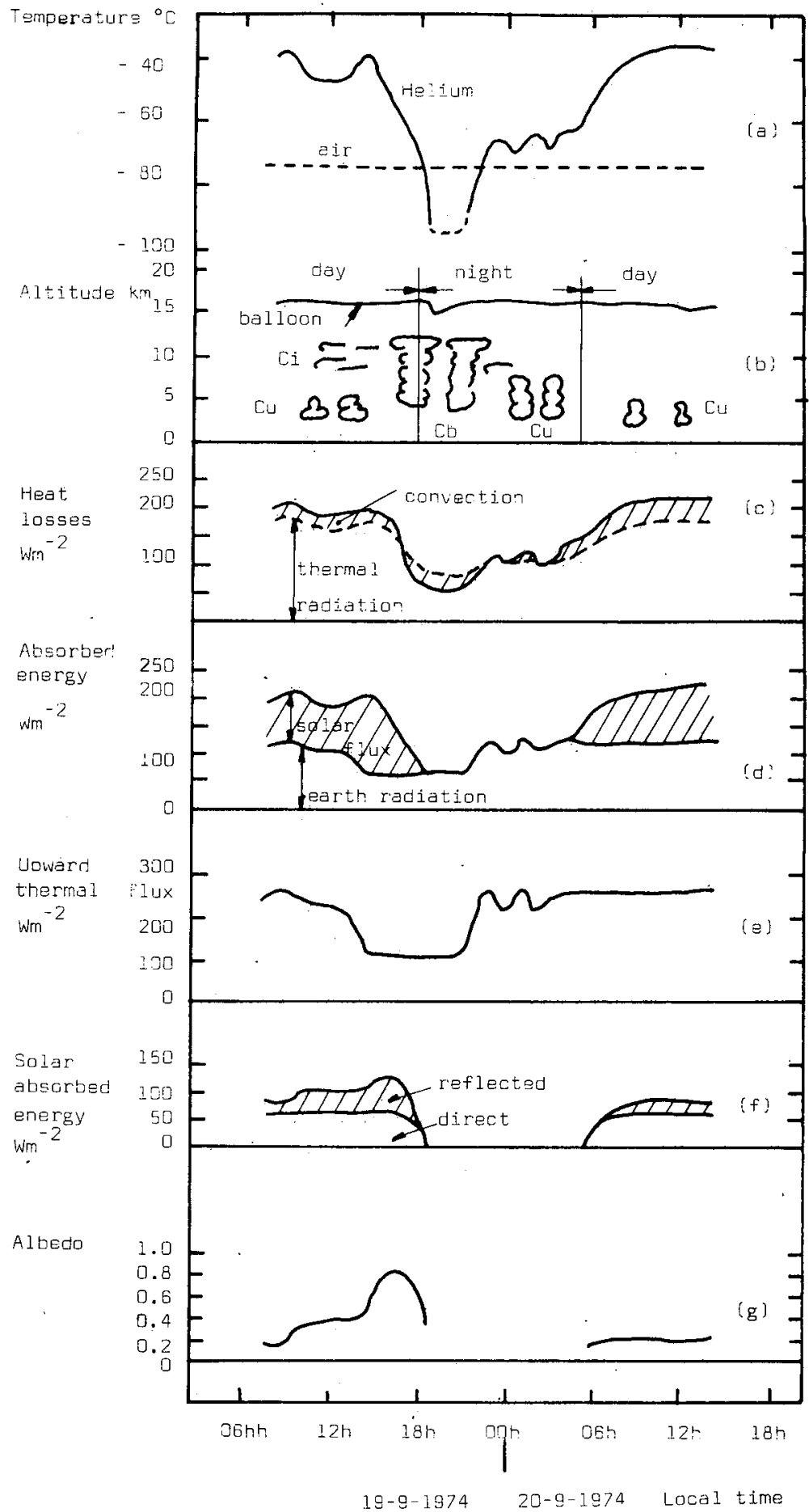

Fig. 6. Thermal balance analysis of a balloon in flight. The heat losses of the balloon by convection and thermal radiation (c) are inferred from the air and helium temperatures (a). They are equal to the absorbed energy (d) which is reduced to the thermal earth radiation at night. During the day the earth radiation is assumed to be equal to that measured at night over the same cloud cover (b). (e) Upward thermal flux through a horizontal surface. The direct solar energy is subtracted from the absorbed solar energy to obtain the reflected solar energy (f) and the solar albedo (g). The heat exchanges are reduced to a balloon of $1 \mathrm{~m}^{2}$ surface. 

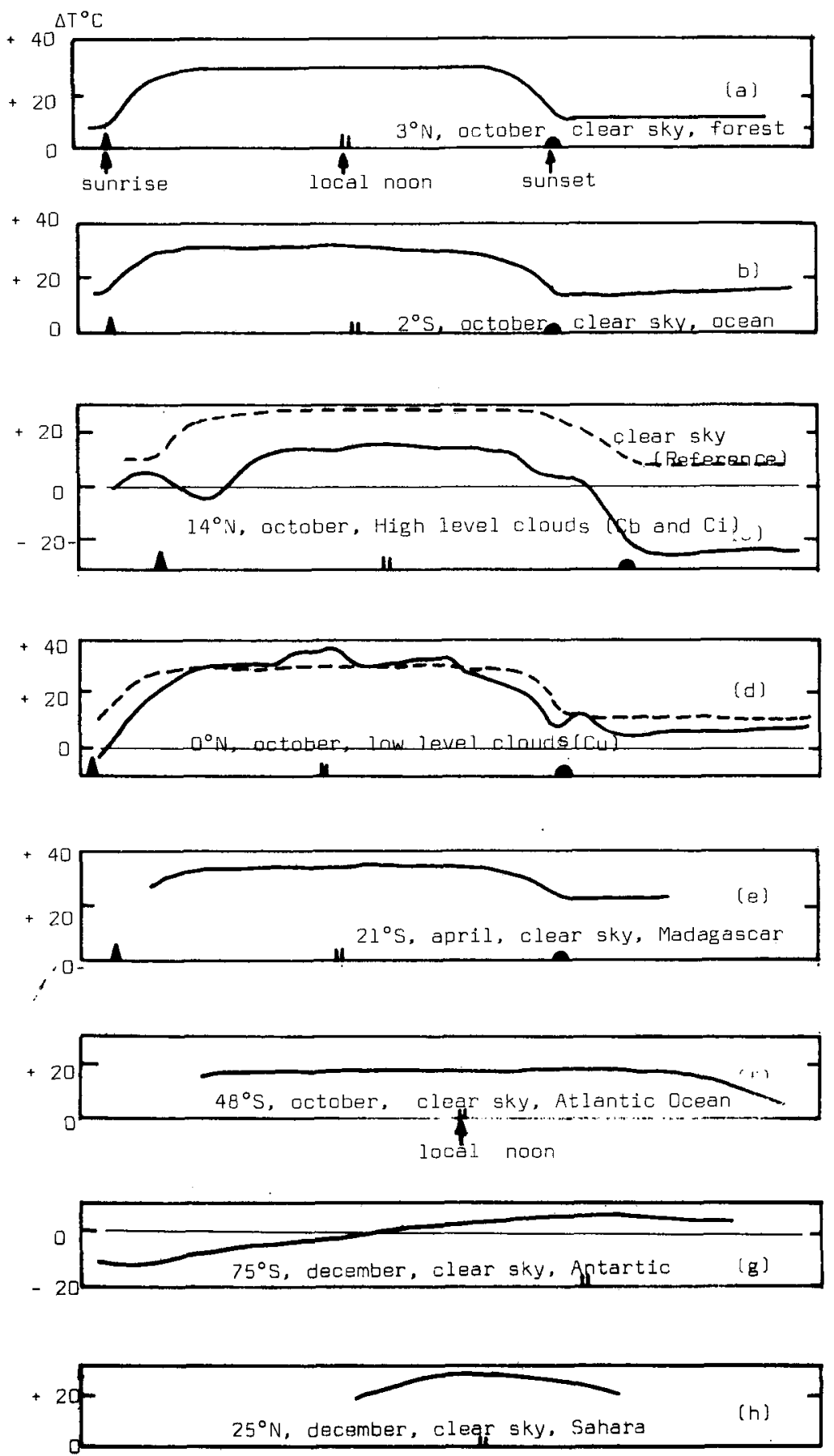

Fig. 7. Temperature difference $(\Delta T)$ between the balloon gas and the surrounding air for seven days of flight. For cloudy conditions the clear-sky reference is shown.

at $15^{\circ} \mathrm{N}$ (Handbook of Geophysics and Space Environments, 1965), the temperature difference is $11^{\circ} \mathrm{C}$. This value and the results of McLeese and Wilson $(1976)\left(15^{\circ} \mathrm{C}\right.$ at $\left.10^{\circ} \mathrm{N}\right)$ are in good agreement with the $9^{\circ} \mathrm{C}$ measured by our experiment.

\section{2) Clear-Sky COnditions}

For clear-sky conditions the thermal flux is much lower in the equatorial region $\left(245 \mathrm{~W} \mathrm{~m}^{-2}\right.$ over the ocean and $225 \mathrm{~W} \mathrm{~m}^{-2}$ over forest) than in tropical 
TABLE 2. Upward thermal fluxes for clear-sky conditions.

\begin{tabular}{|c|c|c|c|c|c|c|c|}
\hline Authors & $\begin{array}{c}\text { Type of } \\
\text { measurements }\end{array}$ & Latitude & Longitude & Geographical area & Date & $\underset{\left(\mathrm{W} \mathrm{m}^{-2}\right)}{\text { Flux }}$ & $\begin{array}{c}\text { Radiation } \\
\text { temperature } \\
(\mathrm{K})\end{array}$ \\
\hline This work & Balloon-100 mb & $\begin{array}{c}0-5^{\circ} \mathrm{N} \\
0-10^{\circ} \mathrm{N} \\
10-20^{\circ} \mathrm{S} \\
40-50^{\circ} \mathrm{S} \\
50-60^{\circ} \mathrm{S} \\
20-30^{\circ} \mathrm{S} \\
20-25^{\circ} \mathrm{S} \\
20-25^{\circ} \mathrm{S}\end{array}$ & $\begin{array}{c}55-75^{\circ} \mathrm{W} \\
85-120^{\circ} \mathrm{W} \\
120^{\circ} \mathrm{W} \\
90-150^{\circ} \mathrm{W} \\
90-150^{\circ} \mathrm{W} \\
35-60^{\circ} \mathrm{E} \\
30^{\circ} \mathrm{E} \\
45^{\circ} \mathrm{E}\end{array}$ & $\begin{array}{l}\text { North Amazonia } \\
\text { Pacific Ocean } \\
\text { Pacific Ocean } \\
\text { Pacific Ocean } \\
\text { Pacific Ocean } \\
\text { Indian Ocean } \\
\text { Transvaal } \\
\text { Madagascar }\end{array}$ & $\begin{array}{l}\text { Oct } 75 \\
" \text { " } \\
\text { Nov } 75 \\
\text { N" } \\
\text { Apr } 78 \\
" \text { " }\end{array}$ & $\begin{array}{l}225 \\
245 \\
257 \\
274 \\
270 \\
292 \\
276 \\
310\end{array}$ & $\begin{array}{l}251 \\
256 \\
259 \\
264 \\
263 \\
268 \\
264 \\
272\end{array}$ \\
\hline \multirow[t]{2}{*}{$\begin{array}{l}\text { Gille and Kuhn } \\
\text { (1973) }\end{array}$} & USA radiometersonde & $6-21^{\circ} \mathrm{N}$ & $79-85^{\circ} \mathrm{W}$ & $\begin{array}{l}\text { Caribbean Sea } \\
\text { and Pacific Ocean }\end{array}$ & May 70 & 285 & 266 \\
\hline & $\begin{array}{l}\text { Japan } \\
\text { radiometersonde } \\
\text { Germany } \\
\text { radiometersonde }\end{array}$ & $\begin{array}{l}6-21^{\circ} \mathrm{N} \\
6-21^{\circ} \mathrm{N}\end{array}$ & $\begin{array}{l}79-85^{\circ} \mathrm{W} \\
79-85^{\circ} \mathrm{W}\end{array}$ & 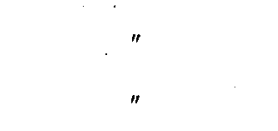 & $"$ & $\begin{array}{l}273 \\
258\end{array}$ & $\begin{array}{l}263 \\
260\end{array}$ \\
\hline $\begin{array}{l}\text { Smith et al. } \\
\text { (1974) }\end{array}$ & Nimbus 5 ITPR & $\begin{array}{l}40^{\circ} \mathrm{N} \\
25^{\circ} \mathrm{N} \\
15^{\circ} \mathrm{S} \\
40^{\circ} \mathrm{S}\end{array}$ & $\begin{array}{l}45^{\circ} \mathrm{W} \\
40^{\circ} \mathrm{W} \\
30^{\circ} \mathrm{W} \\
22^{\circ} \mathrm{W}\end{array}$ & $\begin{array}{l}\text { Atlantic Ocean } \\
\text { Atlantic Ocean } \\
\text { Atlantic Ocean } \\
\text { Atlantic Ocean }\end{array}$ & $\begin{array}{c}\text { Mar } 73 \\
" \\
" \\
"\end{array}$ & $\begin{array}{l}260 \\
298 \\
295 \\
250\end{array}$ & $\begin{array}{l}260 \\
269 \\
269 \\
258\end{array}$ \\
\hline $\begin{array}{l}\text { Vonder Haar } \\
(1970)\end{array}$ & Nimbus 3 MRIR & $\begin{array}{l}15^{\circ} \mathrm{S} \\
25^{\circ} \mathrm{N} \\
30^{\circ} \mathrm{N} \\
25^{\circ} \mathrm{N}\end{array}$ & $\begin{array}{r}125^{\circ} \mathrm{W} \\
55^{\circ} \mathrm{E} \\
105^{\circ} \mathrm{W} \\
5^{\circ} \mathrm{W}\end{array}$ & $\begin{array}{l}\text { NW Australia } \\
\text { Arabia } \\
\text { North Mexico } \\
\text { Sahara }\end{array}$ & $\begin{array}{c}\text { Jun } 69 \\
" \\
" \\
"\end{array}$ & $\begin{array}{l}305 \\
340 \\
320 \\
305\end{array}$ & $\begin{array}{l}271 \\
278 \\
274 \\
271\end{array}$ \\
\hline $\begin{array}{l}\text { Ellingson and } \\
\text { Gille (1978) }\end{array}$ & Model & $13^{\circ} \mathrm{N}$ & & Ocean & & 285 & 266 \\
\hline
\end{tabular}

regions $\left(292 \mathrm{~W} \mathrm{~m}^{-2}\right.$ over the Indian Ocean and $310 \mathrm{~W} \mathrm{~m}^{-2}$ over Madagascar), although the ground and atmosphere temperatures are about the same. Only the radiometersonde measurements (Gille and Kuhn, 1973) are made at the same altitude as ours $(100 \mathrm{mb})$. For clear conditions they are in agreement with our results to within $10 \%$ over the ocean in tropical regions $\left(257-292 \mathrm{~W} \mathrm{~m}^{-2}\right.$ for the balloon results and $258-285 \mathrm{~W} \mathrm{~m}^{-2}$ for the radiometersondes). However, they are made over a limited geographic area. It is interesting to compare the balloon results with those of satellite experiments. In tropical regions the balloon results over the Indian Ocean are in agreement with those of Smith et al. (1974) over the Atlantic Ocean and over dry regions as Madagascar with the high values measured by Vonder Haar (1970) in June 1969 over subtropical deserts like Arabian peninsula, Mexico and the Sahara. In midlatitude over the ocean they are a little higher than those of Smith et al. (1974) (255 $\mathrm{W} \mathrm{\textrm {m } ^ { - 2 }}$ at $45^{\circ} \mathrm{S}$ ). The upward thermal fluxes, computed by the Ellingson and Gille (1978) model for clear conditions and $13^{\circ} \mathrm{N}\left(285 \mathrm{~W} \mathrm{~m}^{-2}\right)$, are near our high values over the tropical Indian Ocean $(292$

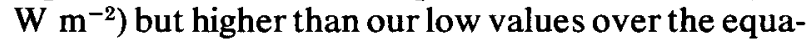
torial Pacific Ocean $\left(245 \mathrm{~W} \mathrm{~m}^{-2}\right)$.

\section{c. Solar albedo}

The balloon results for solar albedo at local noon over various regions for clear and cloudy condi-

TABLE 3. Upward thermal fluxes for high-level clouds.

\begin{tabular}{|c|c|c|c|c|c|c|c|c|}
\hline Authors & $\begin{array}{l}\text { Type of } \\
\text { measurements }\end{array}$ & Latitude & Longitude & $\begin{array}{l}\text { Geographical } \\
\text { area }\end{array}$ & Date & $\underset{\left(W^{-2}\right)}{\text { Flux }}$ & $\begin{array}{l}\text { Radiation } \\
\text { temper- } \\
\text { ature } \\
(\mathbf{K})\end{array}$ & $\begin{array}{l}\text { Temper- } \\
\text { ature } \\
\text { at } 100 \mathrm{mb} \\
(\mathrm{K})\end{array}$ \\
\hline This work & Balloon-100 mb & $\begin{array}{r}0-10^{\circ} \mathrm{N} \\
40-50^{\circ} \mathrm{S}\end{array}$ & $\begin{array}{l}55-75^{\circ} \mathrm{W} \\
55-65^{\circ} \mathrm{W}\end{array}$ & $\begin{array}{l}\text { North Amazonia } \\
\text { Atlantic Ocean }\end{array}$ & $\begin{array}{l}\text { Oct } 75 \\
\text { Oct } 75\end{array}$ & $\begin{array}{r}95 \\
170\end{array}$ & $\begin{array}{l}202 \\
234\end{array}$ & $\begin{array}{l}193 \\
219\end{array}$ \\
\hline $\begin{array}{l}\text { Mac Leese and } \\
\text { Wilson (1976) }\end{array}$ & Nimbus 5 SCR & $4-16^{\circ} \mathrm{N}$ & $17-27^{\circ} \mathrm{W}$ & Atlantic Ocean & $\begin{array}{l}\text { Aug- } \\
\text { Sep } 74\end{array}$ & 106 & 208 & 193 \\
\hline $\begin{array}{l}\text { Cox and Griffith } \\
\text { (1979) }\end{array}$ & $\begin{array}{l}\mathrm{H}_{2} \mathrm{O} \text { measurements } \\
\text { and model }\end{array}$ & $7-10^{\circ} \mathrm{N}$ & $22-25^{\circ} \mathrm{W}$ & Atlantic Ocean & $\begin{array}{l}\text { Aug- } \\
\text { Sep } 74\end{array}$ & 98 & 204 & 193 \\
\hline
\end{tabular}




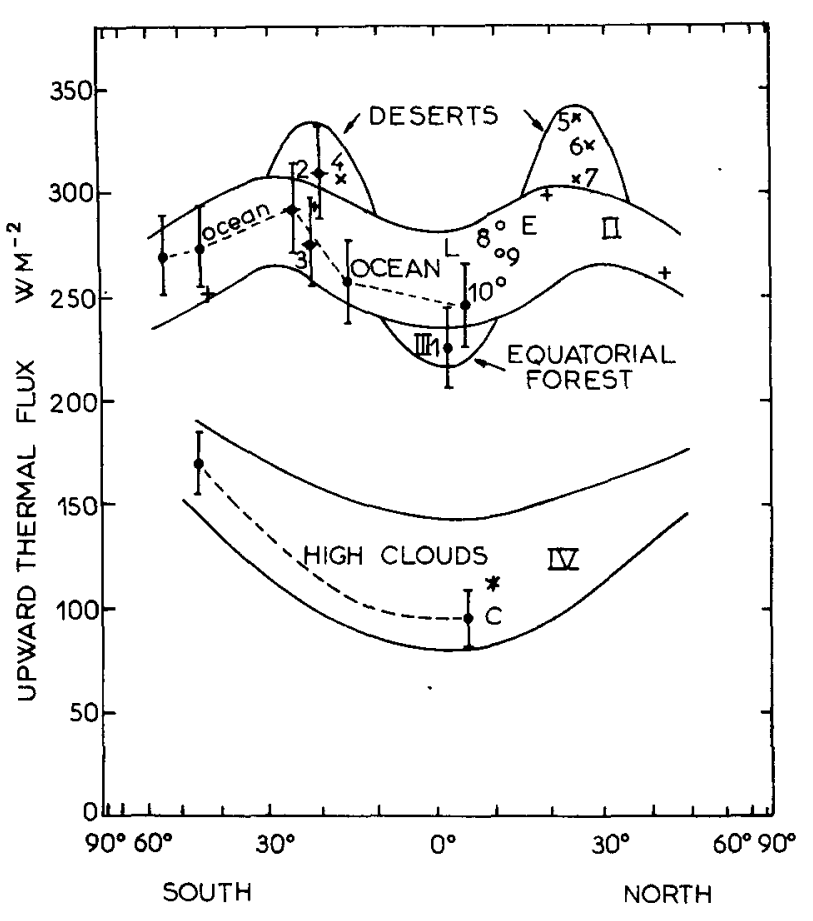

Fig. 8. Upward thermal flux from balloon measurements: This work (with error bars), October $1975(0)$, April $1978(-)$, and (1) North Amazonia, (2) Madagascar, (3) Transvaal; Gille and Kuhn (1973), May 1970, Caribbean Sea and Pacific Ocean (O), and (8) USA, (9) Japan, (10) Germany radiometersondes.

Upward thermal fux from satellite measurements: Smith $e t$ al. (1974), March 1973, Atlantic Ocean, clear sky $(+)$; Vonder Haar (1970), June 1969, clear sky $(\times)$ and (4) N.W. Australia, (5) Arabia, (6) North Mexico, (7) Sahara; Mc Leese and Wilson (1976), August-September 1974, Atlantic Ocean, high clouds (*).

Upward thermal flux from radiative transfert models: Ellingson and Gille (1978), $100 \mathrm{mb}, 13^{\circ} \mathrm{N}$, clear sky (E); Cox and Griffith (1979), $100 \mathrm{mb}, 7-10^{\circ} \mathrm{N}$, high clouds (C).

The observable thermal fux in the stratosphere under clear conditions over subtropical deserts, over ocean, over equatorial forest and over very high clouds are in the I, II, III and IV regions, respectively defined on this figure.

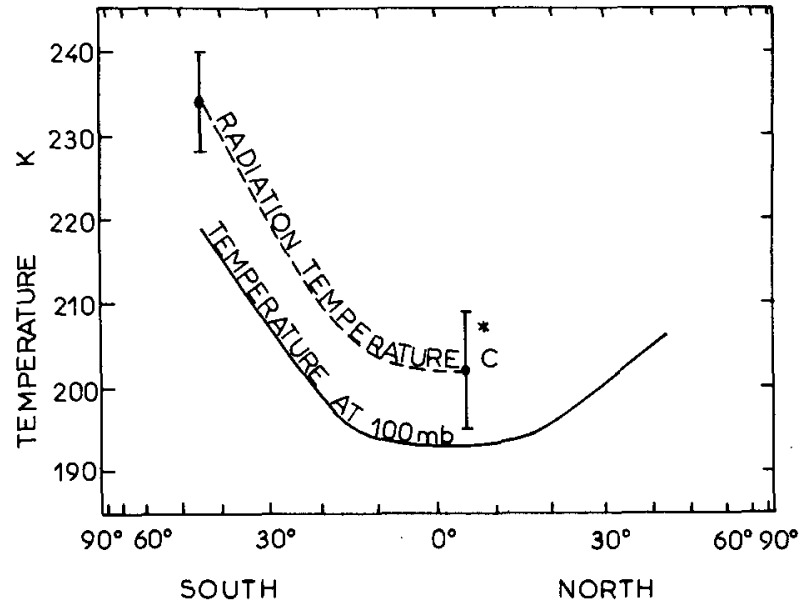

Fig. 9. Radiation temperature of highest clouds and temperature at $100 \mathrm{mb}$. Balloons measurements: This work (with error bars), October $1975(0)$; satellite measurements: Mc Leese and Wilson (1976) (*); Radiative transfer models: Cox and Griffith (1979), $100 \mathrm{mb}, 7-10^{\circ} \mathrm{N}$, high clouds (C).

tions are compared in Table 4 and Fig. 10 with satellite measurements:

- Pyatovskaya's (1972) measurements made from Meteor and Cosmos satellites with plane radiometers.

- Rockwood and Cox (1978) results from simultaneous SMS 1 satellite and aircraft data. Under clear conditions, the albedo seen by the balloon is higher above forest than above ocean. Above clouds the albedo varies greatly with the kind of clouds, between 0.20 above thin cirrus and 0.58 above thick cumulonimbus at local noon. Although the albedo determination through the balloon measurements is indirect and its uncertainty is high, the balloon results for clear-sky condi-

TABLE 4. Albedo determinations of the surface-atmosphere system.

\begin{tabular}{|c|c|c|c|c|c|c|c|}
\hline Authors & $\begin{array}{c}\text { Type of } \\
\text { measurements }\end{array}$ & Latitude & Longitude & Surface & Date & $\begin{array}{l}\text { Surface } \\
\text { albedo }\end{array}$ & $\begin{array}{c}\text { Surface } \\
\text { atmosphere } \\
\text { albedo. }\end{array}$ \\
\hline This work & Balloon $-100 \mathrm{mb}$ & $\begin{array}{l}0-10^{\circ} \mathrm{N} \\
0-5^{\circ} \mathrm{N} \\
0-10^{\circ} \mathrm{N} \\
0-10^{\circ} \mathrm{N} \\
40-50^{\circ} \mathrm{S}\end{array}$ & $\begin{array}{l}85-120^{\circ} \mathrm{W} \\
55-75^{\circ} \mathrm{W} \\
50-75^{\circ} \mathrm{W} \\
50-75^{\circ} \mathrm{W} \\
55-65^{\circ} \mathrm{W}\end{array}$ & $\begin{array}{l}\text { Pacific Ocean } \\
\text { Equatorial forest } \\
\text { Cumulo-nimbus } \\
\text { Thin cirrus } \\
\text { Thick stratus }\end{array}$ & $\begin{array}{c}\text { Oct } 75 \\
" \\
" \\
" \\
"\end{array}$ & & $\begin{array}{l}0.15 \\
0.19 \\
0.58 \\
0.20 \\
0.45\end{array}$ \\
\hline $\begin{array}{l}\text { Pyatovskaya } \\
(1972)\end{array}$ & $\begin{array}{l}\text { Meteor and Cosmos } \\
\text { satellites }\end{array}$ & & & $\begin{array}{l}\text { Ocean } \\
\text { Tropical forest } \\
\text { Stratus }\end{array}$ & $\begin{array}{l}\text { Nov } 69- \\
\text { Feb } 70 \\
" \prime \\
"\end{array}$ & $\begin{array}{l}0.03-0.23 \\
0.13-0.22 \\
0.40-0.76\end{array}$ & $\begin{array}{l}0.08-0.20 \\
0.15-0.22 \\
0.31-0.53\end{array}$ \\
\hline $\begin{array}{l}\text { Rokwood and Cox } \\
\text { (1978) }\end{array}$ & $\begin{array}{l}\text { SMS1 satellite and } \\
\text { aircraft }\end{array}$ & $\begin{array}{l}5-25^{\circ} \mathrm{N} \\
5-15^{\circ} \mathrm{N}\end{array}$ & $\begin{array}{l}15-20^{\circ} \mathrm{W} \\
15^{\circ} \mathrm{W}-5^{\circ} \mathrm{E}\end{array}$ & $\begin{array}{l}\text { Atlantic Ocean } \\
\text { Tropical forest }\end{array}$ & $\begin{array}{l}\text { Jul- } \\
\text { Sep } 74 \\
"\end{array}$ & $\begin{array}{l}0.09 \\
0.15\end{array}$ & $\begin{array}{l}0.13 \\
0.17\end{array}$ \\
\hline
\end{tabular}




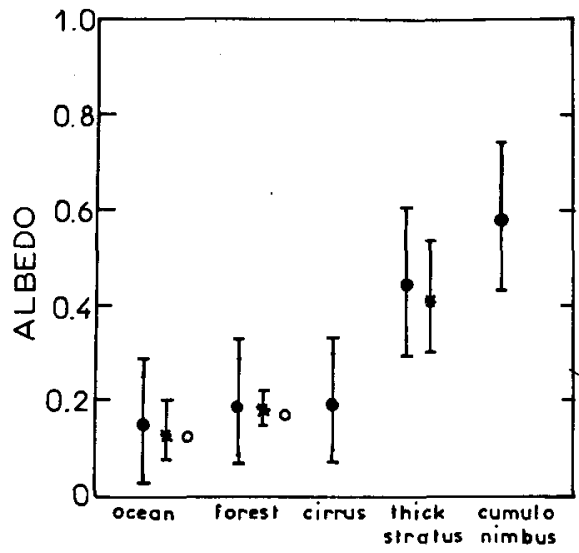

FIG. 10. Solar albedo at local noon. Balloon determinations: This work, October 1975 (with error bars) (O); satellite measurements: Pyatovskaya (1972), November 1969-February 1970 (*); Rockwood and Cox (1978), July-September 1974: (O).

tions and above thick clouds are in good agreement with satellite measurements.

\section{Concluding remarks}

A superpressure constant-level balloon can be used as a radiometer by measuring the helium gas and ambient air temperatures. It allows direct in situ stratospheric determinations of the upwelling thermal radiation over a wide variety of regions. Also, using satellite pictures, the tropospheric albedo can be estimated. Six long-duration flights in the equatorial regions and all the Southern Hemisphere made from 1974 to 1978 lead to the following conclusions.

\section{a. Tropospheric thermal radiation}

1) For clear-sky conditions our results over the ocean in tropical regions are in agreement with the radiometersonde measurements at $100 \mathrm{mb}$ published by Gille and Kuhn (1973).

2) They are also in general agreement with satellite observations and theoretical models, although they give a greater variation with the underlying surface, i.e., $20 \%$ in the tropical areas. Over highlevel clouds, the radiation temperature is always higher, by at least $9^{\circ} \mathrm{C}$ (temperature difference at the equator) than the temperature at $100 \mathrm{mb}$.

\section{b. Solar albedo}

3) The plate albedo, inferred from the reflected solar flux absorbed by a spherical balloon, taking into account the increase of the directional reflectance with zenith angle, is in good agreement with satellite measurements.

Acknowledgments. The authors wish to thank the staff of the Test Ranges of the Centre National d'Etudes Spatiales in French Guyana and of the Council for Scientific and Industrial Research in South Africa who participated in the success of this experiment. We are indebted to Dr. L. Allison of the Goddard Space Flight Center who provided us with the Nimbus 6 infrared pictures and to Dr. T. F. Heinsheimer whose collaboration was very fruitful. This work was supported by the Centre National d'Etudes Spatiales (Contract 75 CNES 201) and the Direction des. Recherches et Etudes Techniques (Contract 73/870) in France.

\section{REFERENCES}

Cox, S. K., and K. T. Griffith, 1979: Estimates of radiative divergence during phase III of the GARP Atlantic Tropical Experiment. Part I. Methodology. J. Atmos. Sci., 36, $576-585$.

Ellingson, R. G., and J. C. Gille, 1978: An infrared radioactive transfer model. Part 1: Model description and comparison of observations with calculations. J. Atmos. Sci., 35, 523545.

Gille, J. C., and P. M. Kuhn, 1973: The International Radiometersonde Intercomparison Programme (1970-1971). Tech. Note 128, WMO, Geneva, 127 pp.

Handbook of Geophysics and Space Environments, 1965: McGraw-Hill, 702 pp.

Handbook of Heat Transfer, 1973: McGraw Hill, 1518 pp.

Lally, V. E., S. B. Solot and S. Ruttenberg, 1967: Circumglobal GHOST balloon flights. Space Research VII, North Holland Publ. Co., 953-957.

Mantis, H. T., 1961: Observation of infrared cooling of a tropical air mass. J. Geophys. Res., 66, 465-476.

McLeese, D. J., and L. S. Wilson, 1976: Cloud top heights from temperature sounding instruments. Quart. J. Roy. Meteor. Soc., 102, 781-790.

Pyatovskaya, N. P., 1972: Atmospheric Radiation Studies, K. Y. Kondratiev, Ed. Leningrad, Gidrometeoizdat, 220 pp. (see pp. 14-27).

Raschke, E., 1969: Angular characteristics of the reflectance of the earth-atmosphere system as obtained from a synchronous satellite. Space Research $I X$, North Holland Publ. Co., 661-667.

Rockwood, A. A., and S. K. Cox, 1978: Satellite inferred surface albedo over northwestern Africa. J. Atmos. Sci, 35, 513-522.

Smith, W. L., D. T. Hilleary, J. C. Fischer, H. B. Howel and H. M. Woolf, 1974: Nimbus S ITPR Experiment. Appl. Opt., 13, 499-506.

Vonder Haar, T. H., 1970: Application of simultaneous infrared radiation measurements and cloud photograph from satellites. J. Appl. Meteor., 9, 955-958. 